\title{
Tali Paranti as A Local Wisdom of Sunda Traditional Society
}

\author{
R Isnendes \\ \{retty.isnendes@upi.edu \} \\ Universitas Pendidikan Indonesia, Indonesia
}

\begin{abstract}
An ethnic that has been tested for its civilization must have rules agreed upon and carried out jointly by its people. Likewise, the Sundanese are the second most populous population in Indonesia. Tali paranti are generally unwritten but to be binding rules, which are carried out on a regular basis or 'commonly implemented'. Scientifically, the tali paranti is in line with tradition or customs. The term of tali paranti in Sundanese is very unique which describes the importance of humans or things that are regulated by humans in their position in the universe. In this study will be discussed: (1) concerning of the term taliparanti, (2) kinds of Sundanese tali paranti, and (3) local wisdom contained in the tali paranti.
\end{abstract}

Keywords: Tali Paranti, Local Wisdom, Traditional, Sunda Society

\section{INTRODUCTION}

Ethnicity which has been tested for its civilization certainly has rules that are agreed upon and carried out jointly by its supporters. Likewise, the Sundanese people are the second largest population in Indonesia. These rules are concepts which are then described in language or provisions, activities, and certain instruments depending on the agreement.

The rules contained in an ethnicity are intelligent ideas of the local community which can be understood as a policy to be carried out together for the sake of peace and shared prosperity as well. That way, wise rules are another form of local wisdom which is a collection of facts, concepts of trust, public perceptions of the surrounding world, can solve problems or conflicts that occur, and validate information[1].

These rules on the culture of Sunda have many references. Some call it adat or customs [2], traditional ceremonies [3], [4], customs [5], life cycle [6], tradition [7], [8], ethics and manners [9], while in general Sundanese people refer to it as a habit, while the elderly and elder (paraji or dukun beranak, also elderly Sundanese who are more than 70 years old) call it paranti rope (interviews with various groups, 2010-2013).

In connection with the mention of the paranti string, Rikin [10], [11] also mentions this term as the title of his dissertation, namely "Ngabersih Als Knoop in The Tali Paranti, Bijdrage tot het Vertsaan van de Besnijdenis der Sundanazen" published by Leiden University. Tali paranti as a rule that became a habit and was obeyed by the Sundanese, also called earlier by Moestapa in 1913 in his book Bab Adat Oerang Priangan djeung Oerang Soenda Lian ti Eta, also by Soeganda in 1962 in his Upacara Adat di Pasundan. Also mentioned by Millie [12]in his book Splashed by The Saint: Ritual Reading and Islamic Sanctity in West Java, was also reviewed by Isnendes [13] in her dissertation "Struktur dan Fungsi Upacara Ngalakssa di Kecamatan Rancakalong Kabupaten Sumedang dalam Perspektif Pendidikan Karakter". 
Paranti rope is generally not written but becomes a binding rule, which is done regularly or 'commonly applied'. Scientifically, paranti rope is in line with tradition or habit. The term string paranti in Sundanese is very unique which describes the importance of humans or things arranged by humans in their position in the universe. In this article, we will discuss: (1) about the term paranti string, (2) the Sunda paranti rope type, and (3) the local wisdom contained in the paranti rope.

\section{RESEARCH METHOD}

The method used is ethnography with observation, literature study, and documentation techniques. The ethnographic method in this study is to record everything related to culture and culture, especially Sundanese culture and culture regarding paranti rope.

Observation techniques are used when observing objects in the form of discourses, terms, concepts, behaviors, and cultural actors, especially those relating to traditional ceremonies in West Java and Baduy which are part of the paranti rope. Library study is an activity to search for important information related to Sundanese paranti rope both recorded and oral, as well as general cultural and traditional information. Registered sources are objects to be documented [14]. However, oral sources are also objects to be documented in this matter. Thus, documentation techniques are used to collect, record, quote, store, and record data from oral or recorded sources.

The data used are all concepts and activities which are considered as Sundanese paranti ropes. Data sources used are: books, journals, communities and Sundanese and Baduy cultural communities, actors in cultural and traditional activities.

\section{RESULT AND DISCUSSION}

\subsection{The Term ofTali Paranti}

The term oftali parantitali or tali karuhun rope based on Sundanese sawér-sawér is interpreted as the secret of life of the ancestors 'karuhun' which must be used as a grip 'cecekelan'. The handle must be carried out by the next generation. Therefore, before the word tali paranti or tali karuhun always begins with the obey 'nurut kana'. So if it is pronounced, it is as follows: according to tali paranti or nurut kana tali paranti. Traditional Sundanese communities in West Java are assumed to know this term.

Somewhat different from in Baduy-Banten. Although it is still included in the Sundanese ethnic group, the Baduy people say that the term that is almost similar to paranti string is ancestral rules 'pikukuh karuhun' and 'amanat asal' or wiwitan mandate. Pikukuh is like a strong framework in the life of the Baduy so that even though the existence of pikukuhpikukuh is inherited verbally, it is firm and binding. Pikukuh karuhun in Baduy is realized by the Baduy community as an awareness of the customs and ancestral heritage that must be maintained and inherited continuously to their children and grandchildren. 


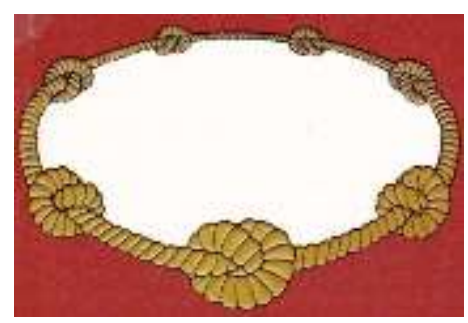

Figure 1. Tali Paranti[10]

Term tali paranti is in practice at Sundanese society is sometimes called paranti, as in this sentence: the parish is like that! 'tos parantina kitu!'. That is one of the answers if asked why should be done activities related to tali paranti. Unlike the term string karuhun, sometimes there are also people who add inserts - ar- to the word 'tali' so that it becomes 'talari'. The true meaning is the same, but it is plural. Why is that? Because the rope that is the handle is knotted in the conclusions of the life cycle of the Sundanese. So there is not only one conclusion but many small conclusions or small ropes from the whole circle of the string. Even if depicted, the paranti rope is like the picture above (Figure 1).

In the picture, the small cords are knotted and form a circle without beginning and without end. But in my opinion, the rope must be open and elongated or dependent; tipped and started to become a rope. Such a rope is like a micro cosmos or a small cosmos that is human life that begins and ends together with other forms: plants, animals, organic and inorganic. The rope can also knot and form spheres like a macro cosmos or a large cosmos (universe) that surrounds humans which is related to control 'cecekelan'; grip 'made by humans as an effort to realize the harmonization of life in marcapada.

Associated with the cosmos, Sundanese people except to compare themselves to the micro and macro cosmos, also believe in the 'real world' and 'the realm is not real'. To maintain harmony or balance, all Sundanese human behavior must be orderly and continuous. Therefore, the results of the processing of reason are manifested as the paranti cord which becomes a guide that can become guidance and control in the life of the Sundanese people.

\subsection{Form of Tali Paranti Sunda}

Tali paranti in Sundanese society is a form of language and behavioral activity as a realization of thoughts and ideas. The activity is of course equipped with accompanying objects as part of its culture. The form of the tali paranti Sundanese people in the language for example only in the form of orders; must; recommendation; compliments (must ... direct 'must be' ... 'so that'), prohibition; reproach (act; pamali; teu meunang), and expressions. The form of activity is in the form of rituals; ceremonies; initiations which he considered could save the cosmos and as a gesture of gratitude for all the blessings that had been given by the God 'Pangéran Nu Murbéng Alam' or 'Gusti Nu Maha Kawasa'.

The tali paranti of the Sundanese community includes: birth, life, and death. Its activities are in the form of ceremonies, for example: tingkeban or nujuh bulan, puputan, mahinum, nurunkeun, ngabersih; sundatan, nikahan, tahlilan, nyusur taneuh, and natus.

Of course, the activities in birth, life and death can be specified specifically according to the customs of each region. Tali paranti is usually done in terms of birth and growth of a child, namely: opat bulanan, nujuh bulanan, babaran, puseur puput, akekah, cukuran (shaving), mere ngaran(giving names),turun bumi, gusaran,dan sundatan. As for the mother after delivery, she is required to take care of vital organs and her body with various kinds of 
necessities, from sitting well to eating food, continued with mahinum, as a form of ending personal hygiene from childbirth and being allowed to relate to her husband.

As for the tali paranti which is related to life in the case of marriage, there are activities which must be carried out as a sign of gratitude to the creator and cultural characteristics of the people, namely: neundeun omong, nyangcang or nyeureuhan, lamaran, seserahan, siraman, ngeuyeuk seureuh, midadarén, nikah (marriage)--in Islamic provisions there are harmonies; special marriage provisions and are covered in marriage. Therefore, from this series of marriages, the activities of these ceremonies by Sundanese-Muslims are considered customary as tali paranti or tali karuhun--sawér, buka panto, nincak endog, ngumbah suku, meuleum harupat, ngaleupaskeun japati, sampai dengan numbas[15].

Tali paranti on death is a number of customary rules that are commonly practiced, although after the 1990s the form of the paranti cord in death was increasingly abandoned. The form of this paranti string, for example: sawer mayit, ngolong, tahlilan (the first day to the seventh day of death), opat puluh poe or matang puluh (40 days of death), natus (100 days of death), and haul (100 days of death), and haul (1000 days of death).

In the Baduy community, pikukuh karuhun is applied standardly in their daily lives as an officially established and structured custom that is systemic on the Baduy traditional calendar from the beginning of the Safar month (Kapat) beginning of the year until the end of the year in Katiga. Of the many pikukuh karuhun categorized as 'mandatory' carried out by all Sundanese Baduy people are kawalu, ngalaksa, and séba.

Paranti rope for Sundanese, not only for humans but also for plants, especially rice[16], [17]. Ways the Sundanese people treat rice are considered as breeding activities for women. That is because in the Sundanese agrarian cosmos there is a myth about the origin of rice, which tells us that rice is created from the body of a woman named Nyi Pohaci; Goddess Sri; Sanghyang Sari Pohaci. The full range of this myth can be read from Sundanese literary works in the form of internalizing the views and orientation of the life of the Sundanese agrarian community [21].

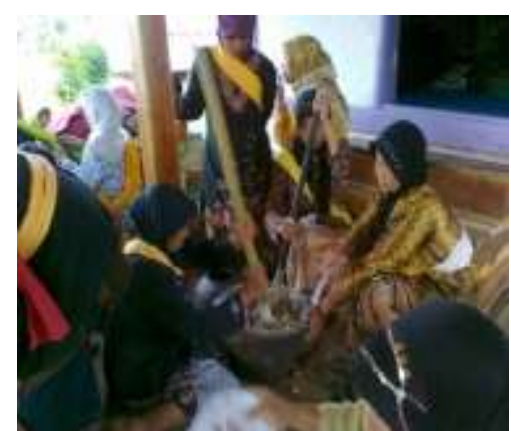

Figure 2. The women in Rancakalong are making laksa (source: Isnendes, 2012)

\subsection{Local Wisdom Found in Tali Paranti}

As a customary rule, tali paranti provides local policies that manifest the intelligence of Sundanese people in observing life issues and their spiritual, spiritual, emotional, mental and physical needs. Tali paranti as a knot is believed to be the grip of life in the realm of the universe which if it holds on to it, people will not get lost in navigating their lives.

Sundanese tali paranti is not only based on reason but also based on the religion it believes. This is in line with Erdogan's opinion [18] that says: "in traditional cultures such as those 
found in Islamic countries, societal values are largely shaped by religious ideology." Therefore, the tali paranti from the beginning until now in its implementation can change, be reduced, added, eliminated, and even created. It depends on knowledge that is recognized by reason, and is considered good in the provisions of religion as adat which contains wisdom called Radiana in the terms al- 'addah al-ma'rifah [19].

Thus, tali paranti or customary rope; habits; tradition; manners; ethics; or whatever the name as something that is considered good will experience reinforcement and there will be repetition since the past until now. The type of tali paranti which is considered bad or al'addah al-jahiliyah will naturally be eliminated and not carried out again.

Aside from being a sign that is a sign, Tali Paranti is a cycle of Sundanese celebration in expressing its gratitude to the Creator who has the universe. This is in line with the results of previous studies which stated that the rope paranti became the representation of the most structured Sundanese tradition along the lines of its life cycle, following the order of celebration that was applied at important moments for them [13].

Tali paranti is a cycle in this Islamic perspective becomes synchronous. It could be that the rules that are summarized in the tali paranti are the embodiment of Sundanese ancestors based on the rules of their Islamic religious beliefs. As is known that around the 15th to the 16th century AD Islam had developed rapidly and was adopted as a system of the sultanate or according to Yus Rusyana in Kartini[20] mentioned "Islam has entered the Pajajaran area in 1522 when the Banten port was visited by many Islamic merchants after Malacca fell to the Portuguese in 1511." After that, the Banten Sultanate was established with the glory championed by Sunan Gunung Jati and Fatahilah from Cirebon before.

Celebration in an Islamic perspective is called gratitude which is realized by greetings. Salametan or celebration (in a simple to luxurious level) is a form of gratitude to God for all His blessings and gifts. In tali paranti, this form of greeting or celebration is found at the peak of traditional ceremonies or traditional activities when carrying out the tali paranti.

\section{CONCLUSIONS}

Sundanese tali paranti, which is the secret of life from ancestors, is actually the rules created by Sundanese humans and carried out in their life activities as a form of effort in achieving safety in the natural world. This tali paranti is also a knot that is used as a handle in the safety of his life, which when it comes to the next knot, Sundanese humans are grateful to realize greetings or thanksgiving. Salametan or sukuran is the essence and culmination of carrying out tali paranti.

Tali paranti varies, but generally exists in three life cycles, namely birth, marriage, and the death of the Sundanese. In addition to the tali paranti found in Sundanese human life, there are also tali paranti in plants, especially rice. Rice is treated as special as a female who is treated as well. In Baduy there is a paranti rope called pikukuh karuhun. Both are found in the Sundanese oral tradition.

As a Sundanese wisdom, the tali paranti is a flexible but binding rule. It is good to keep up with the times and can be formed in accordance with the Shari'a of religion and belief, binding because there are patterns in the form of endless cycles originating from the Sundanese people but starting and finishing for the Sundanese at birth and death.

\section{ACKNOWLEDGEMENTS}

Thank you to the Sundanese tradition and culture in West Java and Banten Baduy. Likewise, a thank you is given to the 2019 PADANG INCOLWIS committee. 


\section{REFERENCES}

[1] A. C. Alwasilah, Etnopedagogik. Bandung: Kiblat, 2009.

[2] H. H. Moestapa, Bab Adat Oerang Priangan djeung Oerang Soenda Lian ti Eta. Batawi: Kandjeng Gupernemen, 1913.

[3] R. A. P. Soeganda, Upacara Adat di Pasundan. Bandung: Sumur Bandung, 1962.

[4] A. Farooq and A. K. Kayani, "Changes in Traditions and Material Exchanges: A Study of a Punjabi Rural Community," Sage Journals - South Asian Surv., vol. 20, no. 1, pp. 150-161, 2015.

[5] R. H. H. Mustapa, Adat Istiadat Sunda. Bandung: Penerbit Alumni, 1996.

[6] J. Danandjaja, Folklor Indonesia: Ilmu Gosip, Dongeng, dan Lain Lain. Jakarta: Pustaka Grafitipress, 2002.

[7] N. H. Lubis, Tradisi dan Transformasi Sejarah Sunda. Bandung: Humaniora Utama Press, 2000.

[8] Kalsum, "Kearifan Lokal dalam Wawacan Sulanjana: Tradisi Menghormati Padi pada Masyarakat Sunda di Jawa Barat," Sosiohumanika, vol. 3, no. 1, 2010.

[9] R. H. Suryalaga, Etika dan Tatakrama. Bandung: Geger Sunten, 2007.

[10] W. M. Rikin, "Ngabersihan Als Knoop in The Tali Paranti, Bijdrage tot het Vertsaan van de Besnijdenis der Sundanazen," Leiden University, 1973.

[11] W. M. Rikin, Peranan Sunat dalam Pola Hidup Masyarakat Sunda. Bogor: n/a, 1994.

[12] J. P. Millie, Splashed by The Saint: Ritual Reading and Islamic Sanctity in West Java. Leiden: Leiden University, 2006.

[13] R. Isnendes, "Struktur dan Fungsi Upacara Ngalakssa di Kecamatan Rancakalong Kabupaten Sumedang dalam Perspektif Pendidikan Karakter," Universitas Pendidikan Indonesia Bandung, 2013.

[14] F. Djajasudarma, Metode Linguistik: Ancangan Metode Penelitian dan Kajian. Jakarta: Refika Aditama, 2006.

[15] U. Muchtar and K. Umbara, Modana. Bandung: PT Mangle Panglipur, 1994.

[16] N. F. Utami, "Inheritance of Social Solidarity Values in Traditional Ceremony of Ngabubur Suro," in The 5th International Conference on Education \& Social Sciences (ICESS), 2017, pp. 397-401.

[17] R. Isnendes, "Ngalaksa in the Folktales of Rancakalong, Sumedang, West Java: A Local Historical Study," TAWARIKH, vol. 10, no. 2, pp. 157-172, 2019.

[18] N. Erdogan, "Cultural Traditions and Domestic Space: Ağaçbekler Home," Sage Journals - South Asian Surv., vol. 7, no. 4, 2017.

[19] A. Radiana, "Kearifan Tradisi dan Budaya Lokal," Pikiran Rakyat, Bandung, p. 18, Mar-2003.

[20] T. Kartini, Puisi Pupujian dalam Bahasa Sunda. Jakarta: Pusat Pembinaan dan Pengembangan Bahasa Departemen Pendidikan dan Kebudayaan, 1986.

[21] K. Saddhono, "Language of Coastal Communities in the Northern Coast of Central Java: Sociolinguistic Studies in Cultural Integration Maritime-Agrarian Perspective." Adv. Sci. Let. vol. 23 no. 10 pp 10054-10056, 2017 